\title{
Protection Mechanism of Clostridium butyricum against Salmonella Enteritidis Infection in Broilers
}

\author{
Xiaonan Zhao, Jie Yang, Lili Wang, Hai Lin* and Shuhong Sun* \\ College of Animal Science and Technology, Shandong Agricultural University, Tai'an, China
}

This study was designed to evaluate the protection mechanism of oral administration of Clostridium butyricum against Salmonella enteritidis (SE) colonization in broilers. In the current study, 180 one-day-old healthy Arbor Acres (AA) broilers were meanly grouped into three, with three replicates of 20 birds each. An negative control group was fed basal diet without SE challenge and a positive control (PC) group was fed the basal diet and challenged with SE $\left[10^{6}\right.$ colony forming unit (CFU)/0.2 mL]. An experimental (EXP) group was fed the basal diet, orally administered with C. butyricum $\left(10^{6} \mathrm{CFU} / \mathrm{mL}\right)$ and challenged with SE (106 CFU/0.2 mL). The results showed that compared to the

OPEN ACCESS

Edited by:

Rebeca Martin

INRA Centre Jouy-en-Josas, France

Reviewed by:

Zhao Chen,

Clemson University, United States Kiiyukia Matthews Ciira,

Mount Kenya University, Kenya Alessandra De Cesare,

Università di Bologna, Italy

*Correspondence:

Shuhong Sun

jaybfkyj@@163.com

Hai Lin

hailin@sdau.edu.cn

Specialty section:

This article was submitted to

Food Microbiology,

a section of the journal

Frontiers in Microbiology

Received: 12 April 2017

Accepted: 28 July 2017

Published: 09 August 2017

Citation:

Zhao $X$, Yang J, Wang L, Lin $H$ and Sun S (2017) Protection Mechanism of Clostridium butyricum against Salmonella Enteritidis Infection in Broilers. Front. Microbiol. 8:1523. doi: 10.3389/fmicb.2017.01523
PC group, the SE loads in livers, spleens, and cecal contents of chickens in EXP group were significantly reduced $(P<0.05)$ except in spleens at the 2-day post-infection; the production of interferon- $\gamma$, interleukin (IL)-1 $\beta$, IL-8, and tumor necrosis factor- $\alpha$ in the livers, spleens, and cecal tissues of chickens in EXP group were decreased to different extents. The results of quantitative real-time polymerase chain reaction further revealed that the inflammation of chickens in EXP group was alleviated by C. butyricum via downregulating TLR4, MyD88, and NF-kB-dependent pathways. Collectively, these findings indicated that oral administration of $C$. butyricum could be a suitable alternative for preventing SE infection in broilers.

Keywords: AA broilers, oral administration, S. enteritidis, C. butyricum, Q-PCR

\section{INTRODUCTION}

Salmonella, as an important foodborne pathogen, can lead to serious infections in animals and humans worldwide (Mead et al., 1999; Scallan et al., 2011). Poultry have been recognized as an important reservoir for Salmonella (Chen and Jiang, 2014). Salmonella can cause high morbidity and mortality in poultry breeding industry, especially in young birds within 1 week age (Wigley et al., 2001; Vo et al., 2006). At the early stage of Salmonella infection, the production of cytokines, such as interferon (IFN) $-\gamma$, interleukin (IL)- $1 \beta$, IL-8, and tumor necrosis factor (TNF)- $\alpha$, is of utmost importance for controlling Salmonella growth and spread in the host body (Brown et al., 2006; Hu et al., 2015). In addition, Toll-like receptors (TLRs) can play a key role in the protection animals and humans against Salmonella infection, and they combat the pathogen through recognition of pathogen-associated molecular patterns (Akira and Takeda, 2004). TLR4, as one important member of the TLRs family, can recognize lipopolysaccharide (LPS) of Gram-negative bacteria and can activate nuclear factor-kappa B (NF- $\mathrm{B}$ ) through myeloid differentiation primary response protein 88 (MyD88), and therefore leading to cytokine secretion and inflammatory response (Kawai and Akira, 2007). 
As for the combat against Salmonella infections, antimicrobials have been widely used in the clinical practice. However, the overuse and even abuse of antibiotics have contributed to the increasing and dissemination of drug-resistant Salmonella and have sparked a severe public health concern (Chiu et al., 2002; Tseng et al., 2014). Furthermore, antimicrobials can lead to the loss of commensal gastrointestinal microbiota and potentially to the overgrowth of pathogens (McDonald et al., 2016; Wischmeyer et al., 2016). Therefore, in the recent years, many researchers have been striving to find the substitutes of antimicrobials, and probiotics are being considered as one of the promising substitute for antimicrobials against Salmonella infections (Mathipa and Thantsha, 2017).

Probiotics have ability to provide protection effects for the host when administered in adequate amounts (Food and Agricultural Organization/World Health Organization [FAO/WHO], 2002). Numerous studies have showed that the use of probiotics is able to modulate mucosal immune functions, prevent bacterial translocation, and potentially suppress inflammatory cytokine production through modulating LPS-induced inflammation by binding to LPS or directly perturbing the MyD88 signaling pathway (Mainous et al., 1995; Kemgang et al., 2014).

Clostridium butyricum, a strictly anaerobic endosporeforming Gram-positive bacillus, could produce butyric acid. Compared to Lactobacillus and Bifidobacterium, C. butyricum is able to survive at lower $\mathrm{pH}$ and relatively higher bile concentrations (Okamoto et al., 2000; Zhang et al., 2016). Previous studies demonstrated that $C$. butyricum can inhibit pathogens propagation and spread in host body and therefore is considered as a potential substitute for antibiotics (Gao et al., 2012; Yang et al., 2012; Zhang et al., 2016). However, the protection mechanism of C. butyricum against Salmonella enteritidis (SE) colonization in broilers remains to be elucidated. This study was therefore conducted to better understand the protection mechanism by which $C$. butyricum protects chickens against SE infection.

\section{MATERIALS AND METHODS}

\section{Ethics Statement}

All procedures were approved by the Animal Care and Use committee of Shandong Agricultural University (SDAUA2016-016).

\section{Bacterial Strains and Growth Conditions}

Clostridium butyricum (AQQF01000149) was obtained as a gift from Dalian Sanyi Animal Medicine Company (China) and grown anaerobically at $37^{\circ} \mathrm{C}$ in liquid fermentation tank for $48 \mathrm{~h}$. The concentration of $C$. butyricum was adjusted to $1 \times 10^{6}$ colony forming unit $(\mathrm{CFU}) / \mathrm{mL}$ in sterile saline.

A virulent atrichia $\mathrm{SE}$, a isolate from a diseased chicken, was obtained from the Avian Disease Centre of Shandong Agricultural University. While cultivating SE, single colony was picked from xylose lysine deoxycholate agar plate and transferred into a tube contained $5 \mathrm{~mL}$ tryptic soy broth and then incubated at $37^{\circ} \mathrm{C}$ for $12 \mathrm{~h}$. The concentration of SE was adjusted to $1 \times 10^{6} \mathrm{CFU} / \mathrm{mL}$ in sterile saline.

\section{Experimental Design}

The experiment was performed in October, 2016. In total, 180 one-day-old healthy Arbor Acres (AA) chickens (negative for Salmonella) were bought from a hatchery in Xintai, China. Chickens were housed in metal cages and provided ad libitum with water and commercial starter diet in the animal room of Shandong Agricultural University. The temperature was maintained at $30^{\circ} \mathrm{C}$ at the first 3 days and gradually reduced to $28^{\circ} \mathrm{C}$ during the last days of the experiment. The nutrient levels of the basal diets met the nutritional requirement of the broilers (NRC, 1994) (Table 1), and the rearing duration lasted 2 weeks. The sanitation of raising environments were regularly cleaned for the health of chicken. Chickens were divided into three treatment groups in random manner: an negative control (NC) group, chickens were orally administrated $0.2 \mathrm{~mL}$ sterile saline per chick once every day through day 1 to day 7 ; a positive control (PC) group, chickens were challenged with $0.2 \mathrm{~mL} \mathrm{SE}$ enrichment solution $\left(10^{6} \mathrm{CFU} / 0.2 \mathrm{~mL}\right)$ at the 8 day, and were given sterile saline $(0.2 \mathrm{~mL} / \mathrm{chick})$ during day 1 to day 7; an experimental (EXP) group, chickens were given $0.2 \mathrm{~mL}$ C. butyricum enrichment solution $\left(10^{6} \mathrm{CFU} / 0.2 \mathrm{~mL}\right)$ once every day from 1 to 7 day, and at the 8 day, chickens were challenged with $0.2 \mathrm{~mL}$ SE enrichment solution $\left(10^{6} \mathrm{CFU} / 0.2 \mathrm{~mL}\right)$. For all groups, chickens were euthanized via cervical dislocation, and livers, spleens, as well as cecal tissues and contents were sampled at 2 and 6 days of post-infection. These samples were frozen at $-80^{\circ} \mathrm{C}$ for further analyses.

\section{SE Translocation}

SE translocation to livers, spleens, and cecal contents of all SE-challenged groups was determined at 2 and 6 days of postinfection. Livers, spleens, and cecal contents were weighted, homogenized respectively and serially diluted 10-fold with sterile

TABLE 1 | The composition and nutrients of basal diet.

\begin{tabular}{|c|c|c|c|}
\hline Ingredient & Content (\%) & Chemical composition & Content \\
\hline Corn & 55.23 & $\mathrm{CP}, \%$ & 20.90 \\
\hline Soybean meal & 30.67 & ME, Mcal/kg & 3.00 \\
\hline Wheat shorts & 4.00 & Calcium, \% & 1.00 \\
\hline Fish meal ${ }^{\mathrm{a}}$ & 3.00 & Total P, \% & 0.65 \\
\hline Soybean oilb & 2.90 & Available P, \% & 0.45 \\
\hline DL-methionine & 0.27 & Methionine + cysteine, \% & 0.90 \\
\hline $\mathrm{NaCl}$ & 0.27 & Lysine, \% & 1.05 \\
\hline Limestone & 1.33 & & \\
\hline Calcium phosphate & 1.33 & & \\
\hline Vitamin-mineral premix ${ }^{C}$ & 1.00 & & \\
\hline
\end{tabular}

${ }^{a}$ Crude protein content is $62.5 \%$ and metabolizable energy is $2.79 \mathrm{Mcal} / \mathrm{kg}$. ${ }^{b}$ Metabolizable energy is $8.8 \mathrm{Mcal} / \mathrm{kg}$. ' Supplied per kilogram of diet: vitamin A (retinyl acetate), 1,500 IU; cholecalciferol, $200 \mathrm{IU}$; vitamin E (DL- $\alpha$-tocopheryl acetate), $10 \mathrm{U}$; riboflavin, $3.5 \mathrm{mg}$; pantothenic acid, $10 \mathrm{mg}$; niacin, $30 \mathrm{mg}$; cobalamin, $10 \mu \mathrm{g}$; choline chloride, $1,000 \mathrm{mg}$; biotin, $0.15 \mathrm{mg}$; folic acid, $0.5 \mathrm{mg}$; thiamine $1.5 \mathrm{mg}$; pyridoxine $3.0 \mathrm{mg}$; Fe, $80 \mathrm{mg}$; Zn, $40 \mathrm{mg}$; Mn, $60 \mathrm{mg}$; $0.18 \mathrm{mg}$; Cu, $8 \mathrm{mg}$; Se, $0.15 \mathrm{mg}$. 
phosphate-buffered saline $(1: 10, \mathrm{w} / \mathrm{v})$, and then screened on Brilliant Green Agar plates (Hopebio, Qingdao, China) to count the CFU of SE after incubation at $37^{\circ} \mathrm{C}$ for $24 \mathrm{~h}$.

\section{Quantitative Real-time Polymerase Chain Reaction}

Quantitative real-time polymerase chain reaction (Q-PCR) was undertaken to relatively quantify the expression levels of cytokine genes including IFN- $\gamma$, IL- $1 \beta$, IL- 8 , and TNF- $\alpha$, and the gene expressions of the MyD88-dependent pathway of TLR4, MyD88, and NF- $\mathrm{BB}$ in the livers, spleens, and cecal tissues. At 2 and 6 days of post-infection, Trizol reagent (Invitrogen) was used to extract total RNA from livers, spleens, and cecal tissues according to the manufacturer's instruction. Nano Drop 2000 spectrophotometer (Thermo Fisher Scientific, MA, United States) was used to determine the concentration and quality of total RNA. SuperScript III First Strand synthesis kit (Life Technologies, Carlsbad, CA, United States) was used to synthesize cDNA with $2 \mu \mathrm{g}$ of total RNA. The cDNA was stored at $-20^{\circ} \mathrm{C}$. The Q-PCR was performed with SYBR Green master mix using 7500 Fast Real-Time PCR system (Applied Biosystems, Carlsbad, CA, United States). PCR conditions contained one cycle of $95^{\circ} \mathrm{C}$ for $30 \mathrm{~s}$, followed by 40 cycles of $95^{\circ} \mathrm{C}$ for $5 \mathrm{~s}$ and $60^{\circ} \mathrm{C}$ for $34 \mathrm{~s}$. Dissociation analysis of amplification products was performed at the end of each PCR to confirm the specificity of amplicon. The primers for real-time PCR are listed in Table 2. mRNA relative expression was calculated using the $2^{-\Delta \Delta C t}$ method.

\section{Statistical Analysis}

The one-way ANOVA and Student's $t$-test of SPSS 15.0 (SPSS Inc., Chicago, IL, United States) were used to perform statistical analyses. The results were shown as mean \pm standard deviations (SD). Differences were considered significant at $P<0.05$.

TABLE 2 | Primers for Q-PCR in this study.

\begin{tabular}{|c|c|c|}
\hline Gene & Sequence $\left(5^{\prime}-3^{\prime}\right)$ & GenBank No. \\
\hline TLR4 & $\begin{array}{l}\text { Forward: AGTCTGAAATTGCTGAGCTCAAAT } \\
\text { Reverse: GCGACGTTAAGCCATGGAAG }\end{array}$ & AY064697 \\
\hline MyD88 & $\begin{array}{l}\text { Forward: TGATGCCTTCATCTGCTACTG } \\
\text { Reverse: TCCCTCCGACACCTTCTITCTA }\end{array}$ & EF011109 \\
\hline NF-кB & $\begin{array}{l}\text { Forward: CAGCCCATCTATGACAACCG } \\
\text { Reverse: TCCCTGCGTCTCCTCTGTGA }\end{array}$ & NM_205129 \\
\hline IFN- $\gamma$ & $\begin{array}{l}\text { Forward: ATCATACTGAGCCAGATTGTTTC } \\
\text { Reverse: ATCATACTGAGCCAGATTGTTC }\end{array}$ & NM_205149. \\
\hline IL-1 $\beta$ & $\begin{array}{l}\text { Forward: GTGAGGCTCAACATTGCGCTGTA } \\
\text { Reverse: TGTCCAGGCGGTAGAAGATGAAG }\end{array}$ & Y15006 \\
\hline IL-8 & $\begin{array}{l}\text { Forward: ATGAACGGCAAGCTTGGAGCTG } \\
\text { Reverse: TCCAAGCACACCTCTCTTCCATCC }\end{array}$ & AJ009800 \\
\hline TNF- $\alpha$ & $\begin{array}{l}\text { Forward: TGCTGTTCTATGACCGCC } \\
\text { Reverse: CTITCAGAGCATCAACGCA }\end{array}$ & AY765397 \\
\hline$\beta$-Actin & $\begin{array}{l}\text { Forward: GAGAAATTGTGCGTGACATCAY } \\
\text { Reverse: CCTGAACCTCTCATTGCCA }\end{array}$ & L08165 \\
\hline
\end{tabular}

\section{RESULTS}

\section{SE Translocation}

The results of SE translocation showed that after 2 and 6 days post-infection, chickens in EXP group significantly reduced the viable count of SE compared to the PC group in the liver, spleen, and cecal content $(P<0.05)$, except in the spleen at 2 day postinfection $(P>0.05)$. In addition, SE was not detected in NC group (Table 3 ).

\section{Gene Expression of Cytokines in the Liver}

At 2-day post-infection, gene expression for pro-inflammatory cytokine TNF- $\alpha$ was significantly elevated in PC group compared to NC and EXP groups $(P<0.05)$, but no significant difference was found between NC and EXP groups $(P>0.05)$; with regard to IFN- $\gamma$, IL- $1 \beta$, and IL-8 production, no significant difference was observed among EXP, PC, and NC groups $(P>0.05)$. At 6-day post-infection in the $\mathrm{PC}$ group, the gene expressions of IFN- $\gamma$, IL- $1 \beta$, and TNF- $\alpha$ were elevated significantly $(P<0.05)$ compared to NC and EXP groups, but no difference was found between NC and EXP groups $(P>0.05)$; in terms of IL-8, no significant differences were found among EXP, NC, and PC groups $(P>0.05)$ (Table 4).

\section{Gene Expression of Cytokines in the Spleen}

At 2-day post-infection, gene expression for IFN- $\gamma$ was significantly increased in PC group compared to NC and EXP groups $(P<0.05)$, but no significant difference was found between NC and EXP groups $(P>0.05)$; in addition, no significant differences were observed in the IL- $1 \beta$ and TNF- $\alpha$ productions among EXP, PC, and NC groups $(P>0.05)$; the expression of IL- 8 was significantly mounted in the PC group compared to EXP group $(P<0.05)$, but no significant difference was observed between EXP and NC groups $(P>0.05)$, and the same change was found between $\mathrm{PC}$ and $\mathrm{NC}$ groups $(P>0.05)$. At 6-day post-infection, gene expressions of IFN- $\gamma$, IL-1 $\beta$, and IL- 8 were elevated significantly in the PC group compared to NC and EXP groups $(P<0.05)$, but no significant difference was found between NC and EXP groups $(P>0.05)$; additionally, no significant difference in the TNF- $\alpha$ production was found among EXP, NC, and PC groups $(P>0.05)$ (Table 5).

\section{Gene Expression of Cytokines in the Cecal Tissues}

At 2-day post-infection, gene expression for IL-1 $\beta$ was significantly elevated in PC group compared to $\mathrm{NC}$ and EXP groups $(P<0.05)$, but no significant difference was found between NC and EXP groups $(P>0.05)$; with regard to IFN- $\gamma$, IL-8, and TNF- $\alpha$ production, no significant difference was observed among EXP, PC, and NC groups $(P>0.05)$. At 6 -day post-infection, gene expressions of IFN- $\gamma$, IL- $1 \beta$, and IL- 8 were elevated significantly in PC group compared to NC and EXP 
TABLE 3 | Effect of $C$. butyricum on the reduction of SE counts in livers, spleens, and cecal contents of broilers ${ }^{1}$.

\begin{tabular}{|c|c|c|c|c|c|c|}
\hline \multirow{2}{*}{ Item } & \multicolumn{2}{|c|}{ Liver } & \multicolumn{2}{|c|}{ Spleen } & \multicolumn{2}{|c|}{ Cecal content } \\
\hline & \multicolumn{2}{|c|}{ Log CFU/organ } & \multicolumn{2}{|c|}{ Log CFU/organ } & \multicolumn{2}{|c|}{ Log CFU/organ } \\
\hline PC & $1.78 \pm 0.29^{a}$ & $1.72 \pm 0.44^{a}$ & $0.72 \pm 0.47$ & $0.63 \pm 0.32^{\mathrm{a}}$ & $5.82 \pm 0.86^{a}$ & $5.48 \pm 0.71^{a}$ \\
\hline EXP & $N D^{b}$ & $N D^{b}$ & $0.42 \pm 0.20$ & $N D^{b}$ & $0.86 \pm 0.12^{b}$ & $0.66 \pm 0.12^{b}$ \\
\hline
\end{tabular}

Mean $\pm S D$ in the same line with different superscript letters differ significantly $(P<0.05) .{ }^{1}$ Each mean represents six birds. PC, birds fed a basal diet and challenged with SE; EXP, birds fed a basal diet with C. butyricum $\left(10^{6} \mathrm{CFU} / \mathrm{mL}\right)$ and challenged with SE. Results show the colony counts of SE in different organs, they are expressed as mean (Log $10 \mathrm{CFU/g}$ of organ) $\pm S D .{ }^{2}$ The days after challenging.

TABLE 4 | Fold changes of cytokine gene expression in the livers of broilers after challenged with $\mathrm{SE}^{1}$.

\begin{tabular}{lcccc}
\hline & & \multicolumn{3}{c}{ Experimental treats } \\
\cline { 3 - 5 } Gene & $\begin{array}{c}\text { Age of } \\
\text { post-ch }\end{array}$ & NC & PC & EXP \\
\hline IFN- $\gamma$ & $2 d$ & $0.001 \pm 0.0001$ & $0.001 \pm 0.0001$ & $0.0007 \pm 0.0001$ \\
& $6 d$ & $0.60 \pm 0.15^{b}$ & $1.36 \pm 0.16^{a}$ & $0.49 \pm 0.04^{b}$ \\
$\mathbb{N}$ L-1 $\beta$ & $2 d$ & $0.64 \pm 0.19$ & $0.71 \pm 0.13$ & $0.89 \pm 0.18$ \\
& $6 d$ & $0.55 \pm 0.05^{b}$ & $1.09 \pm 0.12^{a}$ & $0.31 \pm 0.03^{b}$ \\
IL-8 & $2 d$ & $0.34 \pm 0.06$ & $0.78 \pm 0.11$ & $0.80 \pm 0.21$ \\
& $6 d$ & $0.59 \pm 0.19$ & $1.39 \pm 0.21$ & $0.76 \pm 0.28$ \\
TNF- $\alpha$ & $2 d$ & $0.56 \pm 0.06^{b}$ & $0.92 \pm 0.18^{a}$ & $0.30 \pm 0.14^{b}$ \\
& $6 d$ & $0.83 \pm 0.06^{b}$ & $2.51 \pm 0.32^{a}$ & $1.00 \pm 0.08^{b}$
\end{tabular}

Mean $\pm S D$ in the same row with different superscript letters differ significantly $(P<0.05)$. ${ }^{1}$ Each mean represents six birds. NC, birds fed a basal diet without challenged with SE; PC, birds fed a basal diet and challenged with SE; EXP, birds fed a basal diet with C. butyricum $\left(10^{6} \mathrm{CFU} / \mathrm{mL}\right)$ and challenged with SE. ${ }^{2}$ The days after challenging

TABLE $\mathbf{5}$ | Fold changes of cytokine gene expression in the spleens of broilers after challenged with $\mathrm{SE}^{1}$.

\begin{tabular}{lcccc}
\hline & & \multicolumn{3}{c}{ Experimental treats } \\
\cline { 3 - 5 } Gene & Age of post-ch & NC & PC & EXP \\
\hline IFN- $\gamma$ & $2 \mathrm{~d}$ & $1.00 \pm 0.35^{\mathrm{b}}$ & $2.30 \pm 0.19^{\mathrm{a}}$ & $1.29 \pm 0.12^{\mathrm{b}}$ \\
& $6 \mathrm{~d}$ & $0.39 \pm 0.03^{\mathrm{b}}$ & $1.31 \pm 0.22^{\mathrm{a}}$ & $0.38 \pm 0.01^{\mathrm{b}}$ \\
IL-1 $\beta$ & $2 \mathrm{~d}$ & $0.99 \pm 0.15$ & $2.19 \pm 0.36$ & $1.17 \pm 0.34$ \\
& $6 \mathrm{~d}$ & $0.63 \pm 0.14^{\mathrm{b}}$ & $1.64 \pm 0.22^{\mathrm{a}}$ & $0.32 \pm 0.08^{\mathrm{b}}$ \\
IL-8 & $2 \mathrm{~d}$ & $0.58 \pm 0.22^{\mathrm{ab}}$ & $1.81 \pm 0.28^{\mathrm{a}}$ & $0.30 \pm 0.18^{\mathrm{b}}$ \\
\multirow{2}{*}{ TNF- $\alpha$} & $6 \mathrm{~d}$ & $0.57 \pm 0.09^{\mathrm{b}}$ & $1.95 \pm 0.24^{\mathrm{a}}$ & $0.79 \pm 0.12^{\mathrm{b}}$ \\
& $2 \mathrm{~d}$ & $0.83 \pm 0.11$ & $0.80 \pm 0.10$ & $1.37 \pm 0.49$ \\
& $6 \mathrm{~d}$ & $0.008 \pm 0.0008$ & $0.009 \pm 0.001$ & $0.007 \pm 0.001$ \\
\hline
\end{tabular}

Mean $\pm S D$ in the same row with different superscript letters differ significantly $(P<0.05)$. ${ }^{1}$ Each mean represents six birds. NC, birds fed a basal diet without challenged with SE; PC, birds fed a basal diet and challenged with SE; EXP, birds fed a basal diet with C. butyricum $\left(10^{6} \mathrm{CFU} / \mathrm{mL}\right)$ and challenged with SE. ${ }^{2}$ The days after challenging.

groups $(P<0.05)$, but no significant difference was found between NC and EXP groups $(P>0.05)$; of note, no significant difference in the TNF- $\alpha$ was found among EXP, NC, and PC groups $(P>0.05)$ (Table 6).
TABLE 6 | Fold changes of cytokine gene expression in the cecal tissues of broilers after challenged with $\mathrm{SE}^{1}$.

\begin{tabular}{lcccc}
\hline & & \multicolumn{3}{c}{ Experimental treats } \\
\cline { 3 - 5 } Gene & Age of post-ch & NC & PC & EXP \\
\hline IFN- $\gamma$ & $2 \mathrm{~d}$ & $0.62 \pm 0.11$ & $1.33 \pm 0.17$ & $0.70 \pm 0.22$ \\
& $6 \mathrm{~d}$ & $0.49 \pm 0.07^{\mathrm{b}}$ & $1.37 \pm 0.22^{\mathrm{a}}$ & $0.56 \pm 0.15^{\mathrm{b}}$ \\
IL-1 $\beta$ & $2 \mathrm{~d}$ & $0.80 \pm 0.12^{\mathrm{b}}$ & $1.21 \pm 0.14^{\mathrm{a}}$ & $0.48 \pm 0.11^{\mathrm{b}}$ \\
& $6 \mathrm{~d}$ & $0.66 \pm 0.17^{\mathrm{b}}$ & $1.29 \pm 0.16^{\mathrm{a}}$ & $0.54 \pm 0.12^{\mathrm{b}}$ \\
IL-8 & $2 \mathrm{~d}$ & $0.67 \pm 0.04$ & $0.44 \pm 0.10$ & $0.34 \pm 0.09$ \\
& $6 \mathrm{~d}$ & $0.66 \pm 0.15^{\mathrm{b}}$ & $1.41 \pm 0.16^{\mathrm{a}}$ & $0.50 \pm 0.06^{\mathrm{b}}$ \\
TNF- $\alpha$ & $2 \mathrm{~d}$ & $1.00 \pm 0.08$ & $0.75 \pm 0.17$ & $0.89 \pm 0.18$ \\
& $6 \mathrm{~d}$ & $0.93 \pm 0.08$ & $0.76 \pm 0.17$ & $0.89 \pm 0.18$ \\
\hline
\end{tabular}

Mean $\pm S D$ in the same row with different superscript letters differ significantly $(P<0.05) .{ }^{1}$ Each mean represents six birds. NC, birds fed a basal diet without challenged with SE; PC, birds fed a basal diet and challenged with SE; EXP, birds fed a basal diet with C. butyricum $\left(10^{6} \mathrm{CFU} / \mathrm{mL}\right)$ and challenged with SE. ${ }^{2}$ The days after challenging.

\section{Expression of Genes of the MyD88-Dependent Pathway in Liver, Spleen, and Cecal Tissues}

At 2-day post-infection, no significant difference was observed between EXP and PC groups with regard to the production of TLR4, MyD88, and NF- $\kappa \mathrm{B}$ in liver, spleen, and cecal tissues $(P>0.05)$. However, at 6-day post-infection, gene expressions for TLR4, MyD88, and NF- $\mathrm{B}$ in liver, spleen, and cecal tissues were elevated significantly $(P<0.05)$ in the $P C$ group compared to NC and EXP groups $(P<0.05)$, but no significant differences were found between EXP and NC groups $(P>0.05)$ (Tables 7-9).

\section{DISCUSSION}

In the present study, compared with the PC group, the levels of SE recovered from liver, spleen, and cecal contents were reduced in 1-day-old chickens fed C. butyricum for seven consecutive days, which was in agreement with previous reports (Berndt et al., 2007; Tanedjeu et al., 2016). However, the results were different from another study which indicated that the Salmonella burden in cecal contents was not affected by probiotic treatments while Salmonella infections in liver and spleen were reduced (Yang et al., 2014). The differences may be associated with the types 
TABLE 7 | Expression of genes of the MyD88-dependent pathway in livers ${ }^{1}$.

\begin{tabular}{lclll}
\hline & & \multicolumn{3}{c}{ Experimental treats } \\
\cline { 3 - 5 } Gene & Age of post-ch & \multicolumn{1}{c}{ NC } & \multicolumn{1}{c}{ PC } & \multicolumn{1}{c}{ EXP } \\
\hline TLR4 & $2 \mathrm{~d}$ & $0.78 \pm 0.27$ & $1.21 \pm 0.25$ & $0.99 \pm 0.24$ \\
& $6 \mathrm{~d}$ & $0.81 \pm 0.23^{\mathrm{b}}$ & $2.48 \pm 0.38^{\mathrm{a}}$ & $1.35 \pm 0.28^{\mathrm{b}}$ \\
\multirow{2}{*}{ MyD88 } & $2 \mathrm{~d}$ & $0.66 \pm 0.09$ & $1.01 \pm 0.07$ & $0.63 \pm 0.03$ \\
& $6 \mathrm{~d}$ & $0.81 \pm 0.19^{\mathrm{b}}$ & $1.65 \pm 0.22^{\mathrm{a}}$ & $0.70 \pm 0.10^{\mathrm{b}}$ \\
NF-kB & $2 \mathrm{~d}$ & $0.41 \pm 0.04$ & $0.62 \pm 0.10$ & $0.57 \pm 0.10$ \\
& $6 \mathrm{~d}$ & $0.57 \pm 0.06^{\mathrm{b}}$ & $1.18 \pm 0.11^{\mathrm{a}}$ & $0.41 \pm 0.01^{\mathrm{b}}$
\end{tabular}

Mean $\pm S D$ in the same row with different superscript letters differ significantly $(P<0.05)$. ${ }^{1}$ Each mean represents six birds. NC, birds fed a basal diet without challenged with SE; PC, birds fed a basal diet and challenged with SE; EXP, birds fed a basal diet with C. butyricum $\left(10^{6} \mathrm{CFU} / \mathrm{mL}\right)$ and challenged with SE. ${ }^{2}$ The days after challenging.

TABLE 8 | Expression of genes of the MyD88-dependent pathway in spleens ${ }^{1}$.

\begin{tabular}{|c|c|c|c|c|}
\hline \multirow[b]{2}{*}{ Gene } & \multirow[b]{2}{*}{ Age of post-ch ${ }^{2}$} & \multicolumn{3}{|c|}{ Experimental treats } \\
\hline & & NC & PC & EXP \\
\hline \multirow[t]{2}{*}{ TLR4 } & $2 d$ & $0.75 \pm 0.08$ & $0.85 \pm 0.05$ & $0.93 \pm 0.09$ \\
\hline & $6 d$ & $0.78 \pm 0.18^{b}$ & $1.59 \pm 0.17^{a}$ & $0.66 \pm 0.09^{b}$ \\
\hline \multirow[t]{2}{*}{ MyD88 } & $2 d$ & $1.01 \pm 0.07$ & $1.05 \pm 0.07$ & $0.91 \pm 0.04$ \\
\hline & $6 d$ & $0.80 \pm 0.05^{b}$ & $1.46 \pm 0.15^{a}$ & $0.81 \pm 0.07^{b}$ \\
\hline \multirow[t]{2}{*}{$N F-\kappa B$} & $2 d$ & $1.00 \pm 0.67$ & $0.91 \pm 0.53$ & $0.84 \pm 0.55$ \\
\hline & $6 \mathrm{~d}$ & $0.65 \pm 0.07^{b}$ & $1.54 \pm 0.15^{a}$ & $0.62 \pm 0.13^{b}$ \\
\hline
\end{tabular}

Mean $\pm S D$ in the same row with different superscript letters differ significantly $(P<0.05) .{ }^{1}$ Each mean represents six birds. NC, birds fed a basal diet without challenged with SE; PC, birds fed a basal diet and challenged with SE; EXP, birds fed a basal diet with C. butyricum $\left(10^{6} \mathrm{CFU} / \mathrm{mL}\right)$ and challenged with SE. ${ }^{2}$ The days after challenging.

of probiotics used, breed and age of chickens, as well as rearing environments.

IFN- $\gamma$ is a Th1 cytokine that stimulates macrophages to secret oxidants with antimicrobial activities and is produced by natural killer cells and T-lymphocytes (Alam et al., 2002). In this study, C. butyricum significantly decreased SEinduced IFN- $\gamma$ expression level, which was similar to the report that pretreatment of 1 -day-old chickens with probiotics could significantly reduce IFN- $\gamma$ expression level in Salmonella infection period (Chen et al., 2012).

IL-1 $\beta$ is a major mediator of inflammation in birds and mammals, primarily produced by monocytes, tissue macrophages, and enterocytes (Bar-Shira and Friedman, 2006). In this study, $C$. butyricum significantly decreased SE-induced IL-1 $\beta$ expression level, which was consistent with a previous report which showed that treating Salmonella-infected chicks with Lactobacillus strains could significantly down-modulate the expression level of IL-1 $\beta$ (Chen et al., 2012).

IL-8, as an important member of the chemokines, has chemotactic activity and shares similar structure to cytokines (Baggiolini et al., 1997). The results in this study showed that C. butyricum could significantly reduce mRNA level of IL-8, which was also observed in a previous report (Yi et al., 2016).
TABLE 9 | Expression of genes of the MyD88-dependent pathway in cecal tissues $^{1}$.

\begin{tabular}{lcccc}
\hline & & \multicolumn{3}{c}{ Experimental treats } \\
\cline { 3 - 5 } Gene & Age of post-ch ${ }^{2}$ & NC & PC & EXP \\
\cline { 3 - 5 } TLR4 & $2 d$ & $0.72 \pm 0.12$ & $0.86 \pm 0.15$ & $0.75 \pm 0.14$ \\
& $6 d$ & $0.93 \pm 0.05^{\mathrm{b}}$ & $2.15 \pm 0.23^{\mathrm{a}}$ & $0.81 \pm 0.11^{\mathrm{b}}$ \\
MyD88 & $2 \mathrm{~d}$ & $0.52 \pm 0.08^{\mathrm{b}}$ & $0.92 \pm 0.06^{\mathrm{a}}$ & $0.91 \pm 0.07^{\mathrm{a}}$ \\
& $6 \mathrm{~d}$ & $0.95 \pm 0.05^{\mathrm{b}}$ & $1.59 \pm 0.15^{\mathrm{a}}$ & $0.46 \pm 0.15^{\mathrm{b}}$ \\
NF-KB & $2 \mathrm{~d}$ & $0.92 \pm 0.26$ & $1.22 \pm 0.82$ & $0.97 \pm 0.34$ \\
& $6 \mathrm{~d}$ & $0.83 \pm 0.07^{\mathrm{b}}$ & $1.61 \pm 0.13^{\mathrm{a}}$ & $0.74 \pm 0.15^{\mathrm{b}}$
\end{tabular}

Mean $\pm S D$ in the same row with different superscript letters differ significantly $(P<0.05)$. ${ }^{1}$ Each mean represents six birds. NC, birds fed a basal diet without challenged with SE; PC, birds fed a basal diet and challenged with SE; EXP, birds fed a basal diet with C. butyricum $\left(10^{6} \mathrm{CFU} / \mathrm{mL}\right)$ and challenged with SE. ${ }^{2}$ The days after challenging.

LPS-induced TNF- $\alpha$ factor, as one kind of vital indicator for evaluating inflammatory response in chickens, can produce the inflammatory response in chickens when infected with pathogens (Feng et al., 2016). In the present study, C. butyricum significantly decreased SE-induced the mRNA level of TNF- $\alpha$ in the liver, which was consistent with the report that Lactobacillus rhamnosus may decrease Escherichia coli-induced TNF- $\alpha$ expression level (Liu et al., 2016).

TLR4 plays an essential role in the innate immune response and hence is likely to be involved in young chickens at risk of Salmonella infection ( $\mathrm{Li}$ et al., 2010). In the study, C. butyricum suppressed inflammation by down-regulating TLR4, MyD88, and NF-кB-dependent pathways in chickens with SE infection on day 6 post-infection, which is consistent with the report that indicated that probiotics can decrease pro-inflammatory cytokine levels by inhibiting the expression of TLR4, MyD88, and NF-кBdependent pathways in LPS-induced macrophages and in mice (Song et al., 2015; Yi et al., 2015).

Although there was a limitation in this study (the 2-week rearing period of SE infection experiment was relatively short), these findings indicated that $C$. butyricum can decrease SE infection by down-regulating cytokine gene expression, and can inhibit inflammation by down-regulating TLR4, MyD88, and NF-кB-dependent pathways. Collectively, C. butyricum could be a potential probiotics against SE infection in broiler chickens.

\section{AUTHOR CONTRIBUTIONS}

SS, HL, and XZ designed the work. XZ, JY, and LW raised animals. XZ and JY collected samples. XZ analyzed and interpreted data. XZ drafted the article. SS and HL critically reviewed the article.

\section{FUNDING}

This work was supported by the National key R\&D project (2016YFD0501608 and 2016 YFD0500510); Taishan Scholar Program (201511023); Funds of Shandong "Double Tops" program. 


\section{REFERENCES}

Akira, S., and Takeda, K. (2004). Toll-like receptor signalling. Nat. Rev. Immunol. 4, 499-511. doi: 10.1038/nri1391

Alam, M. S., Akaike, T., Okamoto, S., Kubota, T., Yoshitake, J., Sawa, T., et al. (2002). Role of nitric oxide in host defense in murine salmonellosis as a function of its antibacterial and antiapoptotic activities. Infect. Immun. 70, 3130-3142. doi: 10.1128/IAI.70.6.3130-3142.2002

Baggiolini, M., Dewald, B., and Moser, B. (1997). Human chemokines: an update. Annu. Rev. Immunol. 15, 675-705. doi: 10.1146/annurev.immunol.15.1.675

Bar-Shira, E., and Friedman, A. (2006). Development and adaptations of innate immunity in the gastrointestinal tract of the newly hatched chick. Dev. Comp. Immunol. 30, 930-941. doi: 10.1016/j.dci.2005.12.002

Berndt, A., Wilhelm, A., Jugert, C., Pieper, J., Sachse, K., and Methner, U. (2007). Chicken cecum immune response to Salmonella enterica serovars of different levels of invasiveness. Infect. Immun. 75, 5993-6007. doi: 10.1128/IAI.00695-07

Brown, S. P., Cornell, S. J., Sheppard, M., Grant, A. J., Maskell, D. J., and Mastroeni, P. (2006). Intracellular demography and the dynamics of Salmonella enterica infections. PLoS Biol. 4:e349. doi: 10.1371/journal.pbio.0040349

Chen, C. Y., Tsen, H. Y., Lin, C. L., Yu, B., and Chen, C. S. (2012). Oral administration of a combination of select lactic acid bacteria strains to reduce the Salmonella invasion and inflammation of broiler chicks. Poult. Sci. 91, 2139-2147. doi: 10.3382/ps.2012-02237

Chen, Z., and Jiang, X. (2014). Microbiological safety of chicken litter or chicken litter-based organic fertilizers: a review. Agriculture 4, 1-29. doi: 10.3390/ agriculture 4010001

Chiu, C. H., Wu, T. L., Su, L. H., Chu, C., Chia, J. H., Kuo, A. J., et al. (2002). The emergence in Taiwan of fluoroquinolone resistance in Salmonella enterica serotype Choleraesuis. N. Engl. J. Med. 346, 413-419. doi: 10.1056/ NEJMoa012261

Feng, J. C., Wang, L. H., Zhou, L. X., Yang, X., and Zhao, X. (2016). Using in vitro immunomodulatory properties of Lactic Acid Bacteria for selection of Probiotics against Salmonella infection in broiler chicks. PLoS ONE 11:e0147630. doi: 10.1371/journal.pone. 0147630

Food and Agricultural Organization/World Health Organization [FAO/WHO] (2002). Report of a Joint FAO/WHO Expert Consultation on Guidelines for the Evaluation of Probiotics in Food. London, ON: FAO/WHO of the United Nations.

Gao, Q., Qi, L., Wu, T., and Wang, J. (2012). Ability of Clostridium butyricum to inhibit Escherichia coli-induced apoptosis in chicken embryo intestinal cells. Vet. Microbiol. 160, 395-402. doi: 10.1016/j.vetmic.2012.06.009

Hu, J. L., Yu, H., Raveendra, R. K., Shayan, S., Steve, W. C., Xie, M. Y., et al. (2015). Modulation of cytokine gene expression by selected Lactobacillus isolates in the ileum, caecal tonsils and spleen of Salmonella-challenged broilers. Avian Pathol. 44, 463-469. doi: 10.1080/03079457.2015.1086725

Kawai, T., and Akira, S. (2007). TLR signaling. Semin. Immunol. 19, 24-32. doi: 10.1016/j.smim.2006.12.004

Kemgang, S. T., Kapila, S., Shanmugam, V. P., and Kapila, R. (2014). Cross-talk between probiotic lactobacilli and host immune system. J. Appl. Microbiol. 117, 303-319. doi: 10.1111/jam.12521

Li, P., Xia, P. G., Wen, J., Zheng, M. Q., Chen, J. L., Zhao, J. P., et al. (2010). Up-regulation of the MyD88-dependent pathway of TLR signaling in spleen and caecum of young chickens infected with Salmonella serovar Pullorum. Vet. Microbiol. 143, 346-351. doi: 10.1016/j.vetmic.2009.12.008

Liu, M. C., Wu, Q., Wang, M. L., Fu, Y. H., and Wang, J. F. (2016). Lactobacillus rhamnosus GR-1 limits Escherichia coli-Induced inflammatory responses via attenuating MyD88-Dependent and MyD88-Independent pathway activation in bovine endometrial epithelial cells. Inflammation 39, 1483-1494. doi: 10.1007/s10753-016-0382-7

Mainous, M. R., Ertel, W., Chaudry, I. H., and Deitch, E. A. (1995). The gut: a cytokine-generating organ in systemic inflammation? Shock 4, 193-199. doi: 10.1097/00024382-199509000-00007

Mathipa, M. G., and Thantsha, M. S. (2017). Probiotic engineering: towards development of robust probiotic strains with enhanced functional properties and for targeted control of enteric pathogens. Gut Pathog. 9, 28. doi: 10.1186/ s13099-017-0178-9

McDonald, D., Ackermann, G., Khailova, L., Baird, C., Heyland, D., Kozar, R., et al. (2016). Extreme dysbiosis of the microbiome in critical illness. mSphere 1:e199-e216. doi: 10.1128/mSphere.00199-16
Mead, P. S., Slutsker, L., Dietz, V., McCaig, L. F., Bresee, J. S., Shapiro, C., et al. (1999). Food-related illness and death in the United States. Emerg. Infect. Dis. 5, 607-625. doi: 10.3201/eid0505.990502

Okamoto, T., Sasaki, M., Tsujikawa, T., Fujiyama, Y., Bamba, T., and Kusunoki, M. (2000). Preventive efficacy of butyrate enemas and oral administration of Clostridium butyricum M588 in dextran sodium sulfate-induced colitis in rats. J. Gastroenterol. 35, 341-346. doi: 10.1007/s005350050358

Scallan, E., Hoekstra, R. M., Angulo, F. J., Tauxe, R. V., Widdowson, M. A., Roy, S. L., et al. (2011). Foodborne illness acquired in the United States-major pathogens. Emerg. Infect. Dis. 17, 7-15. doi: 10.3201/eid1701.P11101

Song, D., Zong, X., Zhang, H., Wang, T., Yi, H., Luan, C., et al. (2015) Antimicrobial peptide Cathelicidin-BF prevents intestinal barrier dysfunction in a mouse model of endotoxemia. Int. Immunopharmacol. 25, 141-147. doi: 10.1016/j.intimp.2015.01.017

Tanedjeu, S. K., Suman, K., Venkatesa, P. S., Srinu, R., and Rajeev, K. (2016). Fermented milk with probiotic Lactobacillus rhamnosus S1K3 (MTCC5957) protects mice from Salmonella by enhancing immune and nonimmune protection mechanisms at intestinal mucosal level. J. Nutr. Biochem. 30, 62-73. doi: 10.1016/j.jnutbio.2015.11.018

Tseng, C. S., Yen, Y. C., Chang, C. C., and Hsu, Y. M. (2014). Polymorphism of gene cassette promoter variants of class 1 integron harbored in S. Choleraesuis and Typhimurium isolated from Taiwan. Biomedicine 4, 1-6. doi: 10.7603/s40681014-0020-3

Vo, A. T., Van, D. E., Fluit, A. C., Heck, M. E., Verbruggen, A., Maas, H. M., et al. (2006). Distribution of Salmonella enterica serovars from humans, livestock and meat in Vietnam and the dominance of Salmonella Typhimurium phage type 90. Vet. Microbiol. 113, 153-158. doi: 10.1016/j.vetmic.2005. 10.034

Wigley, P., Berchieri, J. R., Page, A. K. L., Smith, A. L., and Barrow, P. A. (2001). Salmonella enterica serovar Pullorum persists in splenic macrophages and in the reproductive tract during persistent, disease-free carriage in chickens. Infect. Immun. 69, 7873-7879. doi: 10.1128/IAI.69.12.7873-7879.2001

Wischmeyer, P. E., McDonald, D., and Knight, R. (2016). Role of the microbiome, probiotics, and 'dysbiosis therapy' in critical illness. Curr. Opin. Crit. Care 22, 347-353. doi: 10.1097/MCC.0000000000000321

Yang, C. M., Cao, G. T., Ferket, P. R., Liu, T. T., Zhou, L., Zhang, L., et al. (2012). Effects of probiotic, Clostridium butyricum, on growth performance, immune function, and cecal microflora in broiler chickens. Poult. Sci. 91, 2121-2129. doi: 10.3382/ps.2011-02131

Yang, X. J., Brisbin, J., Yu, H., Wang, Q., Yin, F. G., Zhang, Y. G., et al. (2014). Selected lactic acid-producing bacterial isolates with the capacity to reduce Salmonella translocation and virulence gene expression in chickens. PLoS ONE 9:e93022. doi: 10.1371/journal.pone.0093022

Yi, H., Zhang, L., Gan, Z., Xiong, H., Yu, C., Du, H., et al. (2016). High therapeutic efficacy of Cathelicidin-WA against postweaning diarrhea via inhibiting inflammation and enhancing epithelial barrier in the intestine. Sci. Rep. 6, 25679. doi: 10.1038/srep25679

Yi, H. B., Hu, W. Y., Chen, S., Lu, Z. Q., and Wang, Y. Z. (2015). Cathelicidin$\mathrm{BF}$ suppresses intestinal in?ammation by inhibiting the nuclear factor-kappa B signaling pathway and enhancing the phagocytosis of immune cells via STAT1 in weanling piglets. Int. Immunopharmacol. 28, 61-69. doi: 10.1016/j.intimp. 2015.05 .034

Zhang, L., Zhang, L. L., Zhan, X. A., Zeng, X. F., Zhou, L., Cao, G. T., et al. (2016). Effects of dietary supplementation of probiotic, Clostridium butyricum, on growth performance, immune response, intestinal barrier function, and digestive enzyme activity in broiler chickens challenged with Escherichia coli K88. J. Anim. Sci. Biotechnol. 7, 107-115. doi: 10.1186/s40104-0160061-4

Conflict of Interest Statement: The authors declare that the research was conducted in the absence of any commercial or financial relationships that could be construed as a potential conflict of interest.

Copyright (c) 2017 Zhao, Yang, Wang, Lin and Sun. This is an open-access article distributed under the terms of the Creative Commons Attribution License (CC BY). The use, distribution or reproduction in other forums is permitted, provided the original author(s) or licensor are credited and that the original publication in this journal is cited, in accordance with accepted academic practice. No use, distribution or reproduction is permitted which does not comply with these terms. 